\title{
The impact of Europeanization in Cyprus Contract Law and the spill-over to matters of civil procedure
}

Citation for published version (APA):

Mouttotos, N. (2021). The impact of Europeanization in Cyprus Contract Law and the spill-over to matters of civil procedure: more pieces on the mosaic? [Doctoral Thesis, Maastricht University]. Eleven International publishing. https://doi.org/10.26481/dis.20210419nm

Document status and date:

Published: 01/01/2021

DOI:

10.26481/dis.20210419nm

Document Version:

Publisher's PDF, also known as Version of record

\section{Please check the document version of this publication:}

- A submitted manuscript is the version of the article upon submission and before peer-review. There can be important differences between the submitted version and the official published version of record.

People interested in the research are advised to contact the author for the final version of the publication, or visit the DOI to the publisher's website.

- The final author version and the galley proof are versions of the publication after peer review.

- The final published version features the final layout of the paper including the volume, issue and page numbers.

Link to publication

\footnotetext{
General rights rights.

- You may freely distribute the URL identifying the publication in the public portal. please follow below link for the End User Agreement:

www.umlib.nl/taverne-license

Take down policy

If you believe that this document breaches copyright please contact us at:

repository@maastrichtuniversity.nl

providing details and we will investigate your claim.
}

Copyright and moral rights for the publications made accessible in the public portal are retained by the authors and/or other copyright owners and it is a condition of accessing publications that users recognise and abide by the legal requirements associated with these

- Users may download and print one copy of any publication from the public portal for the purpose of private study or research.

- You may not further distribute the material or use it for any profit-making activity or commercial gain

If the publication is distributed under the terms of Article $25 \mathrm{fa}$ of the Dutch Copyright Act, indicated by the "Taverne" license above, 


\begin{abstract}
This dissertation is divided into two parts and seven chapters including the introduction and conclusions. Part I provides the framework upon which the analysis about the impact of EU law is based. Chapter 2 presents the comparative literature on mixed jurisdictions by first analyzing the idea of categorizing legal systems into different classificatory schemes and introducing Cyprus in the so-called 'third legal family', as was developed by Vernon Valentine Palmer, while noting the history and particularities of the legal system of Cyprus. The idea of mixed legal systems as a laboratory of comparative law where a discovery process takes place for new and, potentially, more efficient legal products is also addressed. This issue is inextricably linked with the sub-question about the receptiveness of mixed legal systems in general, and Cyprus law in particular. In Chapter 2 it is highlighted that contract law has been resistant to outside influences since the absorption of legislative deviations from the English paradigm, that is still predominant in Cyprus, is very gradual in practice. The historical development of the legal system of Cyprus, the political conflict that goes on to this day, as well as the financial crisis of 2013, form the basis for the analysis of the current state of the law. In particular, the political conflict has been the major reason for withholding legal reform, pending resolution of the communal dispute, until the financial crisis emphasized the deficiencies and lack of proper institutional infrastructure. The historical background of the legal system reaffirms the perception that the mixed elements of the law are a product of its troubled history.
\end{abstract}

Chapter 3 analyzes the literature surrounding the influence of economic reasoning in law, in particular the legal origins thesis and the idea of systems competition. European law has not been immune to such discussions and institutional competition is promoted at the EU level both between traditional national private law orders as well as between the former and European codification projects. The competition between legal systems has an influence on lawmaking. The reform of the French Civil Code tackled the perceived unattractiveness of the Code that was highlighted by studies such as the Doing Business reports. Substantive contract law is one important facet of this competition among jurisdictions, one that is highlighted by the recent reform of the French Civil Code as well as the measures taken by the European Union in the aftermath of the financial crisis. The legal origins thesis' (LOT) suggestion that financial markets may be an area where the adaptability of judge-made rules, as exemplified by the American Delaware courts, is beneficial, has been challenged after the financial crisis that started from a common law country. Moreover, the competition for the supply of the law results in the introduction of commercial courts that have as an ultimate purpose the enhancement of the 
enforcement of commercial contracts and keeping up with the global judicial competition. The British exit from the EU has further re-energized this competition since it is seen as an opportunity for different jurisdictions to be established as the de facto place for business. Cyprus is also influenced by this competitive process despite the belief that contract law, on the one hand, is considered as being attractive for business since it is closely aligned to the English common law. Procedural law, on the other hand, lacks significantly behind since the resolution of commercial disputes which are lengthy an inefficient, creates disincentives for commercial parties to choose Cyprus as a basis for doing business.

Finally, Chapter 3 emphasizes the fact that commercial parties when choosing a particular jurisdiction or law that will govern their contract, they take into account substantive aspects of the law such as the unequivocal recognition of the freedom to contract, the availability of commercially-oriented remedies and the reluctance of courts to re-write commercial contracts (something that is linked to the absence or presence of any general duty of good faith). However, the financial crisis has led to the resurgence of the requirement of good faith found in Directive 93/13 as a result of the jurisprudence of the Court of Justice of the EU (CJEU), adopting a civilian approach as far as the enforcement of contracts. Such contracts are unenforceable in civil law systems in case of severe information asymmetries that would breach the trust of the uninformed party. Legislative measures by the EU and CJEU judgments adopt a similar stance towards such information asymmetries, something that has a major impact on Cyprus contract law which is primarily based on the idea of caveat emptor.

Chapter 4 lays the theoretical foundation for the analysis that follows, in particular, with relation to contract law in the aftermath of the financial crisis. The idea of fairness in contracts is examined along with issues of allocation of risk and inequality of bargaining power as well as the position under Cyprus law. The interpretation of contracts and the textual and contextual approaches to contractual interpretation is analyzed in Chapter 4, a recurring topic in the analysis in Part 2.

Part 2 of this dissertation analyzes the impact of EU law in certain areas of the law in order to attend to the main research question. This influence has been mainly a result of the consumer acquis, especially Directive 93/13, and the need for protecting consumers from standard form contracting that violates the requirement of good faith and creates a significant imbalance in the parties' rights and obligations. Chapter 5 examines the impact of EU law upon consumer contracts in Cyprus, especially the consumer of financial services, by reference to the jurisprudence of Cyprus courts, also making cross-comparisons with jurisdictions that have been influential to the 
elaboration of Cyprus law. A large number of claims from debtors for mis-selling practices by financial institutions came before courts, the result of which and the reasoning of the courts is examined in Chapter 5 as well as the influence of EU law on the banker-customer relationship as a result of legislative instruments such as MiFID (I and II). Furthermore, an extensive part of the analysis is dedicated to the legislative control of fairness and the consumer acquis, which has posed considerable challenges for the courts in Cyprus the reasoning of which is based on traditional doctrines of consent (such as the doctrine of contractual estoppel). The changing discourse as a result of the public enforcement of EU law is highlighted at the end of this Chapter which shows that consumer protection in Cyprus is primarily driven by public enforcement by sectorial regulators, while being still in its infancy before the courts. Along with common law and civil law, European law in the sense of the Regulations and Directives emanating from the EU, form an integral part of Cyprus law that according to the Constitution has precedence over national Constitutional provisions. Moreover, a new level of legal activity and legal discourse has been added to the traditional legal system of Cyprus. Thus, Cyprus law is developing into a complex amalgam consisting of many different juridical traditions and components in contrast to its narrow common law parameters before independence.

Chapter 6 presents the changes in civil procedure in Cyprus and the effect of EU law upon such developments. Furthermore, it is shown that through European directives on consumer law, EU law finds its way into national procedural law, despite the principle of procedural autonomy. An examination of the changes in civil procedure is necessary since the EU, especially with the recent steps taken through the New Deal for Consumers, has given particular emphasis on the effective implementation of EU law and the procedural mechanisms available for remedying violations of EU law, especially consumer law. This is in line with the general realization that enforcement is crucial for the functioning of substantive law. It is argued in this Chapter, that the prevalent understanding in the EU of procedural law as a vehicle for enforcing EU norms is challenging the traditional model of party disposition/party autonomy. However, Cyprus courts have been resilient to such developments and public enforcement of rights (thus, through sectorial regulators) granted under EU law is becoming the norm in Cyprus. It is expected, though, that with the New Deal for Consumers that this influence will become more pronounced.

Lastly, Chapter 7 addresses the conclusion of the analysis about the impact of EU law upon contract law and civil procedure in Cyprus. The conclusions follow the sequence of the research questions in attempting to provide answers to the main research question by first addressing the sub-questions posed and finally returning to the main research question. The conclusions can be further contextualized if the reader returns to the analysis and the closing remarks of each chapter. 